\title{
第8回アジア学術会議(青島)ワークショップ 「ジェンダー・中小企業・ICT」報告
}

山本畺鳥・原ひろ子

\section{回 ICTの必要性、広く認識される}

司会は袖井孝子（連携会員、お茶の水女子大学） とシャムシア・アハマド（インドネシア科学院、 インドネシア）が、オーガナイザーは原ひろ子 (連携会員、城西国際大学)、山本眞鳥（会員、法 政大学)、袖井孝子が務めた。まず、ワークショッ プに先立ち、5月下旬の四川大地震により亡くなっ た方への追悼、被災者への激励が表明された。さ らに、災害において女性・子ども・高齢者が被災 しやすいこと、拈よび、復興過程における女性の 役割が重視されるべきことが指摘された。今回の テーマに含まれるICT * は、災害リスクに詨する防 備を強化し、持続可能なコミュニティの再建を実 践する上で大きな役割を有する。

最初に、シャムシア・アハマドが、2005年ハノ イ会議に打いて正式に承認されたSCA Joint Projectの一環である、通称ジェンダー・ワークシ ヨップの経緯を説明した。ICTが開発全般に果た す役割の重要性は広く認識されてきているが、ICT が男女共同参画と女性のエンパワーメントにどれ

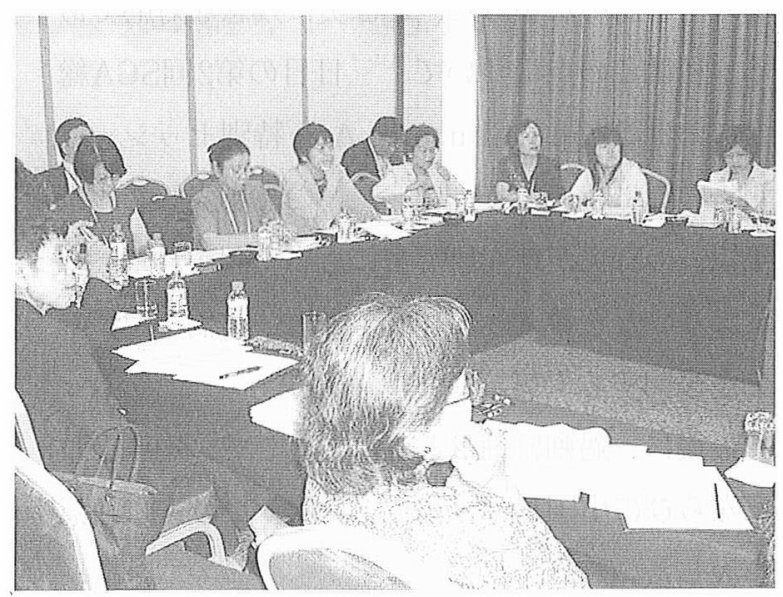

だけ貢献するかは、いまな推題とされている。 こうした課題に取り組むためには、中小企業とICT 分野に扔いて、ジェンダー、生活全般、人権を重 視する新しいアプローチが必要であるという認識 に基づき、本ワークショップは企画された。コン セプシオン (チャット)・ガルシア・ラミロ (APC、 フィリピン)、ワティ・ヘルマワティ/アチエ・ $\mathrm{S}$ ・ルフリマ(インドネシア科学院、インドネシ ア）は、アジアに沏ける女性ICT起業家の状況を 概観し、具体的な事例を報告した。例えば、ブー タンの非都市部で織物業を営む起業家の女性たち は、ビジネス・プランを作成し、国内外の市場で の販路開拓・拡大のためにICTを活用している。 また、インドネシアでは、インターネットを利用 して花异の販売を行うバーチャル・ショップの例 がある。帯野久美子（特任連携会員、インターア クト・ジャパン、日本）はICTを駆使した諸事業 を国際的に展開している。世界各地に散在するス タッフをネットワーク化して業務を遂行しており、 年齢差別・人種差別・ジェンダー差別のないダイ バーシティーの理念を貫いている。

張健（中華女子学院、中国）は現在進行中の調 查研究の中間報告として、中国女性の生活へのICT の影響を考察した。中国女性は男性とほぼ同様の 頻度でICTを利用しているが、女性ユーザはイン ターネットで発信される伝統的な女性イメージの 影響を受けやすい。楊魯慧と師鳳蓮（山東大学、 中国）は、中国女性の政治・経済への参加はかな り進んでいるとはいえ、近年ではむしろ後退気味 であり、男女共同参画の完全な実現には至ってい ないと指摘した。 
Qingdao Municipal People's Governmen Organized by

Science Council of Japan

China Associ an for Sciance and Techn Dingdao Asso - in in anse and Tech

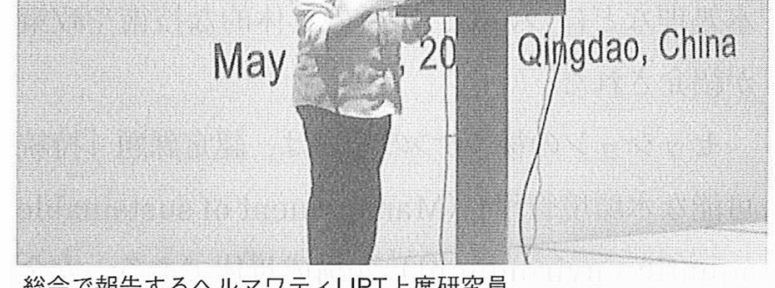

総会で報告するヘルマワティLIPT上席研究員

圖 負の課題解決と女性参画の振興を

本ワークショップでは、女性の生活へのICTの 負の影響についても着目すべきであることが明ら かにされた。ヘルマワティ/ルフリマはインドネ シアに打けるICT分野でのジェンダー格差につい て述べた。ガルシア・ラミロはインターネット技 術へのアクセス・知識・トレーニングの分野で生 起している新しいジェンダー格差について報告し た。キャロリン・I・ソブリッチャ（フィリピン大 学、フィリピン) は、コメンテーターとして、ICT の負の局面、例壳ば人身取引や売買春、ポルノグ ラフィーに言及し、それらの犠牲者の多くは女性 と少女であることを指摘した。政府・国際社会・ メディア等との連携によって、そうした負の局面 を取り除く手だてが必要であると主張した。ナン シー・ルイス（太平洋学術協会、米国）は、アジ アに抢いては完全な男女共同参画に向けて不断の 努力がいまなお必要であるとコメントした。村松 安子（特任連携会員、東京女子大学、日本）は、 いかにICTを利用してジェンダーと開発の理念を 実現していくかが、われわれの課題であるとのコ メントを寄せた。

このワークショップには、10カ国35名の男女が

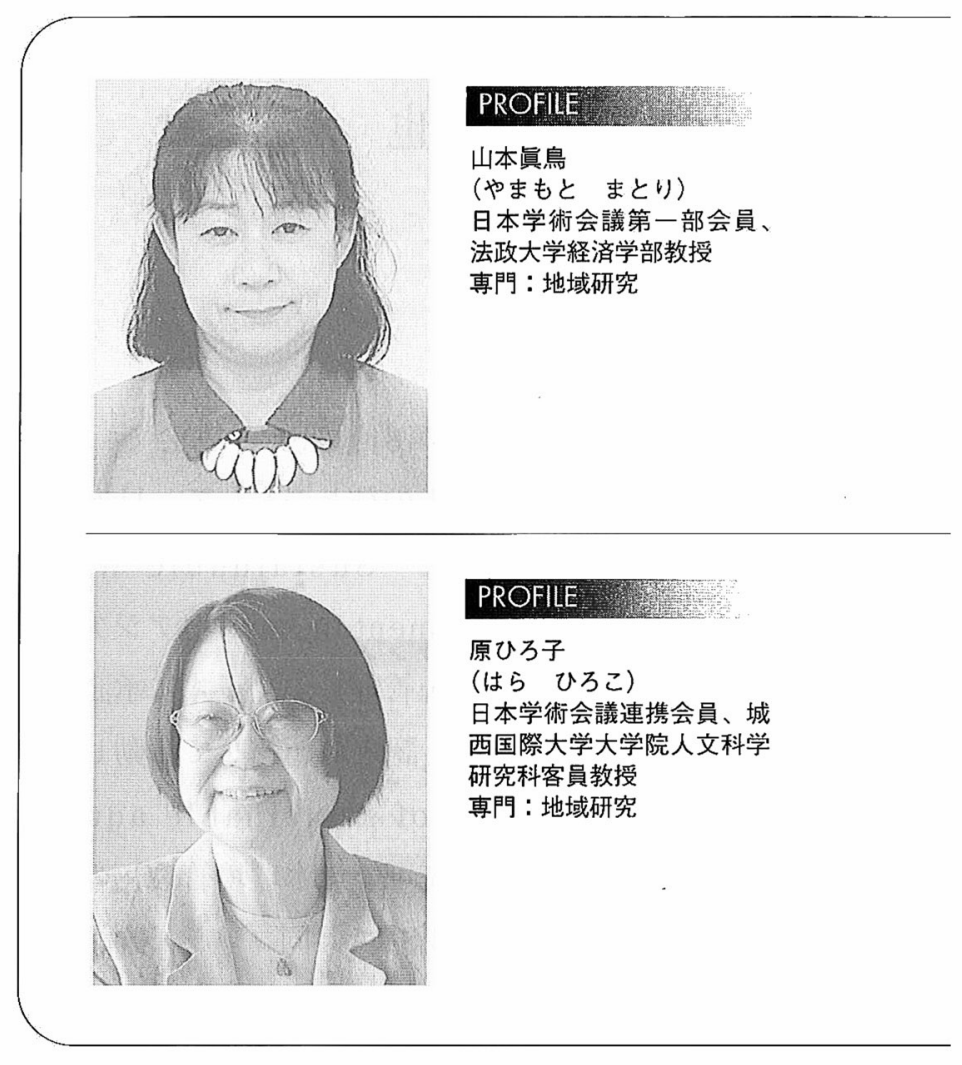

参加し、さまざまな立場から白熱し高揚した議論 を展開した。結論として、ICTの有効利用は女性 のエンパワーメントと起業の成功をもたらす契機 となっており、NGOや女性団体の活性化にも貢献 している。しかし、アジアの貧困層の大部分を占 める女性は未だにICTへの平等なアクセスを享受 していない。ICTはまた、ジェンダー・ステレオ タイプの持続や人身取引など、女性の生活に負の 影響をもたらしている。これらの課題の解決と科 学技術分野へのアジア地域の女性の参画を振興す る役割について、アジア学術会議に対する強い期 待が表明された。

次回シンガポールで開催される第9回アジア学術 会議においては、「アジアにおける科学的才能の育 成一ジェンダーの視点から」(仮題) というワーク ショップを開催する予定である。

* Information and communication technology 